\title{
Komunikasi Organisasi Bidang Reservasi Hotel
}

\author{
Redi Panuju, I Kadek Narena \\ Universitas Dr. Soetomo \\ J1. Semolowaru No.84, Menur Pumpungan, Sukolilo, Kota SBY, Jawa Timur 60118 \\ ren_regenzee@yahoo.com, redipanuju@gmail.com
}

Masuk tanggal : 13-8-2018, revisi tanggal : 06-11-2018, diterima untuk diterbitkan tanggal : 20-5-2019

\begin{abstract}
Bali tourism is growing rapidly even though there was a decline due to bomb terror and Mount Agung's increased activity. This tourism development is followed by the rapid growth of the hospitality business to support the provision of accommodation services. Each hotel has particular employee who will make it easier for guests to make reservations. Reservations employee have a very complex task that must be considered in order to provide the best service. In general, organizational communication in the Pullman Bali Legian Beach (PBLB) Hotel Reservation (HR) Department has so far run well, but there are things that should be improved if the work appreciation or career level \& communication climate needs to be improved related to the factors that influence work motivation. This study uses a qualitative approach. Data obtained by in-depth interviews with key informants from HR in PBLB. Based on the analysis results, it is known that the communication styles used are very diverse ranging from controlling, structured, twoway and very dynamic communication styles. The communication climate at the PBLB reservation office is also good. So far, the communication skills from the reservation team is considered good, and they also realize it is the main capital to carry out their profession as a reservation employee.
\end{abstract}

Keywords: communication style, organizational communication, organizational climate

\begin{abstract}
Abstrak
Pariwisata Bali berkembang pesat meski sempat terjadi penurunan akibat teror bom dan aktifitas Gunung Agung yang meningkat. Perkembangan pariwisata ini diikuti dengan berkembang pesatnya bisnis perhotelan untuk membantu menunjang penyediaan jasa akomodasi. Setiap hotel memiliki karyawan reservasi yang mempermudah tamu untuk melakukan pemesanan. Karyawan bidang reservasi memiliki tugas yang sangat kompleks mengingat banyak hal yang harus diperhatikan guna memberikan pelayanan yang terbaik. Secara umum komunikasi organisasi dibidang Reservasi Hotel Pullman Bali Legian Beach (PBLB) sejauh ini berjalan baik namun ada hal-hal yang perlu ditingkatkan, seperti apresiasi kerja atau jenjang karir dan iklim komunikasi terkait faktor yang mempengaruhi motifasi kerja. Penelitian ini menggunakan pendekatan kualitatif. Data diperoleh dengan wawancara mendalam terhadap informan kunci dari SDM bidang Reservasi. Berdasarkan hasil analisis diketahui gaya komunikasi yang di pakai sangatlah beragam mulai dari gaya komunikasi mengendalikan, terstruktur, dua arah dan sangat dinamis. Iklim komunikasi di kantor reservasi PBLB juga baik. Sejauh ini terlihat kemampuan berkomunikasi dari tim reservasi baik dan merekapun menyadari itu sebagai modal utama menjalani profesi mereka sebagai seorang karyawan bidang reservasi hotel.
\end{abstract}

Kata Kunci: gaya komunikasi, iklim organisasi, komunikasi organisasi 


\section{Pendahuluan}

Bali merupakan sebuah nama yang sudah tidak asing di dunia. Tidak hanya keindahan alamnya namun keragaman budayanya yang berjuta menjadi salah satu daya tarik yang luar biasa. Tidak hanya sampai disitu keramah-tamahan dan kesantunan masyarakat Bali juga menjadi daya magnet yang kuat untuk memikat daya tarik wisatawan berkunjung ke Bali. Hal ini pasti sangat menggembirakan dan sekaligus menjadi peluang bagi masyarakat Bali untuk meraup keuntungan dan rezeki dari sektor pariwisata. Ekspedisi penjelajahan wisata oleh masyarakat internasional di Bali telah dimulai pada awal abad ke-20 dimana sebelumnya bahwa pulau Dewata Bali ditemukan oleh warga Belanda tahun 1579 oleh ekspedisi (Cornellis de Houtman) dalam perjalanannya mengelilingi dunia untuk mencari kekayaan rempah-rempah lalu tiba di Indonesia.

Dimulai dari kepulauan Jawa misi tersebut berlanjut menuju ke arah timur dan dari kejauhan terlihatlah sebuah pulau yang teramat lebat. Disangka pulau itu menghasilkan rempah-rempah. Setelah mereka menepi, tidaklah rempah-rempah yang ditemukan. Melainkan sebuah kehidupan dengan kekayaan kebudayaannya yang menurut mereka sangat unik, belum pernah dijumpai di tempat lain yang dikunjungi selama mereka mengarungi samudra mengelilingi dunia, alamnya sangatlah indah dan mempunyai keunikan tersendiri. Pulau ini disebut dengan nama Bali. Hal inilah yang mereka laporkan kepada Raja Belanda kala itu. Berlanjut pada sekitar tahun 1920 mulai berdatangan wisatawan dari benua Eropa ke Bali. Hal ini terjadi berkat dari kapal dagang Belanda KPM (Koninklijke Paketcart Maatsckapy) dalam tujuannya mencari rempah ke Indonesia dan juga agar kapal-kapal tersebut mendapat penumpang dalam perjalanannya ke Indonesia dan dikenalkanlah Bali di Daratan Eropa sebagai (the Island of God). (Sujatno, 2008)

Berawal dari wisatawan Eropa yang mengunjungi daratan Bali terdapat pula para pecinta kesenian, diantaranya seniman sastra, seniman lukis maupun seniman seni tari. Dalam kunjungan selanjutnya banyak diantara mereka akhirnya menulis tentang kekayaan Bali seperti: seniman sastra dan seniman lukis. Himawan (2013) mensitir pendapat Caroline Turner, peneliti seni rupa kebangsaan Australia, yang mengatakan bahwa perkembangan seni rupa kontemporer di Bali dianggap sebagai cermin perkembangan dan perubahan masyarakat kontemporer.

Para wisatawan asing yang sudah menikmati keindahan Bali membawa pulang dan menceritakan pengalaman selama di Bali kepada sanak saudaranya. Penyebaran informasi mengenai Bali dengan tulisan-tulisan tentang Bali maupun cerita dari mulut ke mulut menyebabkan Bali makin mendapatkan perhatian manca negara. Bahkan sampai saat inipun nama besar Bali tetap lebih bergema dibandingkan dengan nama Indonesia di kancah mancanegara.

Untuk mengakomodasi wisatawan asing yang ingin menikmati ke eksotisan tanah Bali maka di tahun 1930 didirikanlah hotel pertama di Bali yaitu, Bali Hotel yang berlokasi di kota Denpasar dan sebuah pesanggrahan di kawasan Kintamani. Pesanggrahan sangatlah strategis untuk dapat melihat pemandangan cantik Kintamani yang unik dan mempunyai daya tarik tersendiri di mata 
wisatawan. Promosi hotel menjadi semakin mudah seiring dengan penggunaan teknologi informasi dan aplikasi yang memberi akses kemudahan pembelian secara online (Wijaya \& Santoso, 2018)

Dari Tahun 1969 hingga tahun 2014 kemajuan dibidang pariwisata sangat meningkat. Pada bulan Februari tahun 2011 di pantai kuta juga suda dibuka sebuah hotel dibawah naungan ACCOR worldwide Cooperation yang bernama Pullman Bali Legian Beach (PBLB) Hotel. Hotel ini sudah tujuh (7) tahun lebih beroperasi dan cukup mendapatkan perhatian masyarakat yang tidak hanya lokal tapi juga menyasar pada market Asia, Australia, Afrika, Eropa dan Amerika. Perkembangan dan kemajuan dari Hotel Pullman Bali Legian Beach pastinya tidak terlepas dari kinerja dan manajemen dan karyawan yang baik. Turut ambil bagian di dalamnya adalah bagian reservasi sebagai media pertama yang dihubungi oleh tamu saat akan melakukan pemesanan kamar, baik melalui surat elektronik, fax, ataupun telepon.

Secara umum di kantor reservation Hotel PBLB komunikasi organisasi termasuk keadaan iklim komunikasinya cukup baik, namun hal ini harus ditingkatkan mengingat tugas dari seorang karyawan reservasi cukup kompleks. Dimulai dari menerima pesanan kamar, melakukan proses pemesanan kamar melalui Opera System (sistem operasional yang digunakan hotel Pullman Bali Legian Beach), melakukan proses pembayaran. Salah satu hal mendasar yang harus ditingkatkan adalah adanya standar internasional yang harus dipenuhi yaitu, target Resavision yang merupakan salah satu kriteria brand standard sebagai anggota hotel ACCOR internasional yang menjadi tolak ukur keberhasilan tim dan penilaian hotel di mata dunia. Resavision ini adalah audit wajib yang dilakukan setiap bulannya kepada seluruh Hotel ACCOR berisikan uji standar internasional yang harus dilakukan oleh tim reservasi. Jadi dapat dikatakan jejaring ACCOR Hotel ini memiliki standar international untuk menyelaraskan pelayanan kepada tamu di seluruh dunia. Oleh karena itu, manajemen dan tim reservasi wajib mengoptimalkan komunikasi organisasi yang terjalin agar semua informasi terkait perencanaan, pelaksanaan dan evaluasi Resavision guna pencapaian target dan penilaian yang ditetapkan dapat diraih.

Sebagai orang yang pertama melayani tamu meskipun tidak bertemu atau bertatap muka secara langsung, kemampuan berkomunikasi yang baik sangat diperlukan guna menghindari terjadinya hal yang dapat merugikan, seperti kesalahpahaman mengenai informasi. Kesalahan tersebut akan berdampak pada operasional hotel dan berimbas pada ketidakpuasan tamu. Hal ini dapat berakibat buruk pada kemajuan dan pemasaran hotel di masa mendatang. Kini tantangannya adalah peningkatan wisata dan persaingan tidak hanya pada harga tapi juga lebih pada pelayanan sebagai modal utama mendapatkan kepuasan tamu dan citra hotel.

Di area Kuta beberapa hotel seperti The Stone, Sheraton dan Hard Rock Hotel merupakan pesaing dari hotel Pullman Bali Legian Beach. Hotel - hotel ini selalu mengembangkan kualitas pelayanan termasuk juga kualitas dari staff masing masing supaya dapat melayani secara maksimal di berbagai lini termasuk bagian reservasi. Kinerja dari seorang karyawan reservasi dipengaruhi banyak aspek, selain kemampuan komunikasi tetapi juga komunikasi organisasi. 
Komunikasi organisasi ialah bentuk pertukaran pesan antara unit-unit komunikasi yang berada dalam suatu organisasi. Organisasi terdiri dari unit-unit komunikasi dalam hubungan-hubungan yang saling berketerkaitan satu dengan yang lainnya dan fungsi masing-masing dalam lingkungan itu sendiri. Manusia dalam hal ini terlibat sebagai subyek dalam proses menerima, menafsirkan, dan bertindak atas informasi. Komunikasi organisasi adalah pengiriman dan penerimaan bermacam pesan organisasi di dalam kelompok yang formal maupun informal dari suatu organisasi. Dijelaskan pula bahwa komunikasi formal merupakan komunikasi yang disetujui oleh organisasi dan sifatnya berorientasi kepentingan dari organisasi itu sendiri. Adapun komunikasi informal merupakan komunikasi yang disetujui secara social, yang berorientasi tidak pada organisasi, tetapi lebih kepada anggotanya sebagai individual. Fakta dalam sebuah penelitian menunjukkan bahwa komunikasi yang bersifat informal memiliki efektivitas dalam komunikasi organisasi (Sulistyo, 2009).

Komunikasi organisasi serupa dengan komunikasi internal. Definisi komunikasi internal merupakan pertukaran gagasan di antara para manajemen dan karyawan dalam suatu perusahaan, dalam struktur lengkap yang biasanya disertai pertukaran sudut pandang secara horisontal dan vertikal di dalam suatu perusahaan, sehingga pekerjaan dapat dilaksanakan (Panuju, 2018)

Menurut Steward L. Tubbs dan Sylvia Moss (1996), gaya komunikasi mengendalikan (The Controlling Style) ditandai dengan adanya satu kehendak untuk membatasi, memaksa dan mengatur perilaku, pikiran dan tanggapan orang. Orang-orang yang menggunakan gaya komunikasi seperti ini lebih dikenal dengan nama komunikator satu arah atau one-way communications. Pribadi-pribadi yang memakai controlling style of communication ini, lebih menitikberatkan perhatian pada pengiriman pesan dibanding upaya mereka untuk menerima pesan. Mereka cenderung tidak mempunyai rasa ketertarikan dan perhatian untuk pesan lainnya. Mereka tidak mempunyai rasa ketertarikan dan perhatian pada umpan balik, namun akan berbeda jika umpan balik atau feedback tersebut digunakan untuk kepentingan pribadi mereka. Para komunikator satu arah ini tidak khawatir dengan pandangan buruk akan dirinya, tetapi justru akan menggunakan kewenangan dan kekuasaan untuk memaksa orang lain mematuhi pandanganpandangannya. Pesan-pesan yang berasal dari komunikator satu arah ini, tidak berusaha mendiskusikan gagasan secara bersama namun lebih pada usaha menjelaskan kepada orang lain apa yang akan dilakukannya. The controlling style of communication ini sering dipakai untuk mempersuasi orang lain agar bekerja dan bertindak secara efektif, dan pada umumnya dalam bentuk kritik. Komunikasi yang sering terdengar negatif ini menyebabkan orang lain memberi respons dan tanggapan yang negatif pula.

Gaya komunikasi berikutnya adalah The equalitarian style of communication. Dalam gaya komunikasi ini, aktifitas komunikasi dilakukan secara terbuka. Setiap anggota organisasi berkesempatan mengungkapkan gagasan ataupun pendapat dalam suasana yang rileks, santai dan informal. Dalam suasana yang demikian, memungkinkan setiap anggota organisasi mencapai kesepakatan dan pemahaman bersama. Aspek penting gaya komunikasi ini ialah adanya landasan kesamaan. The equalitarian style of communication ini ditandai dengan 
berlangsungnya arus penyebaran pesan-pesan baik verbal, secara lisan dan tertulis yang bersifat dua arah (two-way communication). Orang-orang yang menggunakan gaya komunikasi ini, adalah mereka yang memiliki sikap solidaritas tinggi serta kemampuan menjalin hubungan yang baik dengan orang lain baik dalam konteks pribadi maupun dalam lingkup hubungan kerja. The equalitarian style ini akan memudahkan suatu tidakan komunikasi dalam organisasi, karena gaya ini efektif dalam menumbuhkan empati dan kerja sama, khususnya dalam situasi untuk mengambil keputusan terhadap suatu permasalahan yang kompleks. Arif Sehfudin \& Fuad Mas'ud (2011) membuktikan adanya hubungan antara gaya komunikasi dengan motivasi kerja di suatu perusahaan.

Gaya komunikasi yang berstruktur ini, memanfaatkan pesan-pesan verbal secara tertulis maupun lisan guna menegaskan perintah yang harus dilaksanakan, pengaturan jadwal tugas dan pekerjaan serta struktur organisasi. Pengirim pesan lebih memberi perhatian kepada keinginan untuk memengaruhi orang lain dengan jalan berbagi informasi tentang tujuan organisasi, jadwal kerja, aturan dan prosedur yang berlaku dalam organisasi tersebut.

Gaya komunikasi ini memiliki kecenderungan lebih agresif, karena pengirim pesan atau sender memahami bahwa lingkungan pekerjaannya berorientasi pada tindakan (action-oriented). The dynamic style of communication ini sering dipakai oleh para juru kampanye ataupun manejer yang membawa para wiraniaga. Tujuan utama gaya komunikasi yang agresif ini adalah mestimulasi atau merangsang karyawan untuk bekerja dengan lebih cepat dan lebih baik. Gaya komunikasi ini efektif digunakan dalam mengatasi persoalan yang bersifat kritis, namun dengan persyaratan bahwa karyawan atau bawahan mempunyai kemampuan yang cukup untuk mengatasi suatu persoalan tersebut. Gaya ini lebih mencerminkan kesediaan untuk menerima saran, pendapat ataupun gagasan dari orang lain, daripada untuk memberi perintah, meskipun pengirim pesan mempunyai hak untuk memberi perintah dan mengontrol orang lain. Pesanpesan dalam gaya komunikasi ini akan efektif ketika sender sedang bekerja sama dengan orang-orang yang berpengetahuan luas, berpengalaman, teliti serta integritas atas semua tugas atau pekerjaan yang dibebankan kepadanya. Akibat yang muncul jika gaya ini digunakan adalah melemahnya tindak komunikasi, artinya gugurnya keinginan dari orang-orang yang memakai gaya ini untuk berkomunikasi dengan orang lain tanpa terkecuali, karena ada beberapa persoalan ataupun kesulitan antarpribadi yang dihadapi oleh orang-orang tersebut. Oleh karena itu, gaya ini tidak patut dipraktekkan dalam komunikasi organisasi. Safruddin Wahid (2014) menambahkan bahwa gaya komunikasi disesuaikan dengan situasi dan kondisi yang ada. Dalam kondisi terdapat kepercayaan yang tinggi terhadap organisasi, maka gaya komunikasi yang cenderung memberi ganjaran berupa pujian sangat dibutuhkan, sebaliknya di suatu organisasi yang cenderung loyalitas berkurang maka gaya otoritarian acapkali dibutuhkan untuk menegakkan kedisiplinan.

Komunikasi organisasi dapat dianalisis dengan beberapa obyek diantaranya gaya komunikasi yang dipakai, bagaimana komunikasi organisasi yang terjalin, bagaimana pendekatan komunikasinya yang dipakai sehingga dapat terlihat keadaan karyawan atau tim, motivasi kerjanya dan keadaan iklim 
komunikasinya agar dapat memahami faktor yang dapat merangsang motivasi kerja terkait peningkatan pelayanan yang berujung pada kemajuan perkembangan hotel.

\section{Metode Penelitian}

Penelitian ini menggunakan pendekatan kualitatif dengan tipe studi lapangan (field research). Data diperoleh melalui wawancara dan observasi terhadap sumber daya manusia yang bertanggung jawab di bidang reservasi di hotel Pulman Bali Legian Beach. Hasil wawancara dan observasi direduksi sedemikian rupa sehingga sesuai dengan kepentingan analisis, yakni melihat proses pelayanan terhadap reservasi dari sudut pandangan komunikasi organisasi. Arikunto (2000) menerangkan bahwa penelitian di lapangan bukan hanya sekedar mengamati fenomena empirik yang terjadi dalam level interaksi antara manusia dengan manusia, namun juga mengamati informasi yang disediakan oleh media internet. Antonius Burowo (2004) menambahkan dalam penelitian kualitatif dibutuhkan kecermatan dalam memaknai data sehingga peneliti perlu melakukan cross check dengan data yang lain melalui triangulasi data, baik data skunder, maupun data primer yang diperoleh dari hasil wawancara. Sugiyono (2010) menekankan agar dalam menggali data dari informan jangan sampai ada tekanan atau intimidasi, sehingga informan memberikan data secara tidak jujur atau apa adanya. Hal tersebut menyebabkan kemungkinan data menjadi tidak atau kurang valid.

Wawancara dilakukan di kantor reservasi Pullman Bali Legian Beach pada hari Senin tanggal 28 Mei 2018. Observasi dilakukan kurang lebih selama 1 bulan terhitung dari tanggal 1 - 31 Mei 2018. Wawancara dilakukan kepada enam (6) karyawan reservasi yang terdiri dari Reservation Manager Ibu Kristina, Reservation Agent yaitu Asty, April, Deri dan Novi. Pengamatan dilakukan mulai dari pengerjaan email sampai penyelesaian laporan pekerjaan dilakukan dengan pengawasan dan monitor langsung oleh Reservation Manager sehingga karyawan diharuskan bekerja secara terstruktur dan terarah sesuai dengan standar yang dikeluarkan ACCOR Hotel.

\section{Hasil Penemuan dan Diskusi}

Hasil analisis menunjukkan gaya komunikasi dapat terlihat dari semua karyawan yang sangat agresif merespon semua permasalahan untuk ditindak lanjuti demi ketepatan waktu bekerja, selain itu staf juga sangat terbuka dengan segala macam kritik dan saran. Oleh karenanya, komunikasi yang terjalin secara umum berjalan baik. Hal ini didukung dengan kondisi lapangan dimana staf sangat aktif bertukar informasi berkenaan dengan reservasi tamu. Media komunikasi yang dominan digunakan oleh karyawan bidang reservasi adalah email, telepon, fax dan juga komunikasi secara langsung. 
Permasalahan komunikasi yang sering terjadi dalam bentuk missed communication, dikarenakan persepsi atau human error, tidak dipungkiri kesalahan pasti akan ada. Hal ini dapat berakibat yakni tamu merasa kurang puas sehingga mengajukan komplain, dan memberikan review yang buruk pada hotel. Masalah yang juga sering muncul biasanya mengenai harga kamar hingga masalah pelayanan. Didapatkan juga keterangan bahwa kadang ada saja tamu yang biasanya mencari celah untuk melakukan kecurangan agar mendapatkan tambahan keuntungan dari manajemen seperti dengan sengaja melakukan keluhan mengenai kamar atau pelayanan dan lainnya.

Permasalahan komunikasi di bidang reservasi hotel sangat kompleks dan berhubungan dengan semua departemen, sehingga missed communication ini berpeluang menjadi masalah internal dan eksternal. Cara yang dilakukan untuk meminimalisir missed communication adalah dengan menanyakan ke sumbernya langsung, menyampaikan semua informasi secara tepat dan efektif, dan menanyakan kembali jika ada informasi yang kurang jelas, memastikan lawan bicara atau yang diberikan informasi nyaman dan merasa dihargai saat berbicara dan memastikan betul bahwa semua informasi yang disampaikan atau didapatkan dimengerti. Bidang reservasi setelah melakukan pembicaraan atau komunikasi verbal melalui telepon, maka mereka akan melakukan backup supporting document dengan mengirimkan email konfirmasi kepada tamu atau rekan-rekan operasional bersangkutan.

Permasalahan menyangkut kinerja reservasi biasanya cukup mudah didapatkan solusinya melalui pengarahan rutin yang bertujuan agar kepala dari setiap bagian atau departemen dapat menyampaikan permasalahan dan bertukar pikiran atau membagikan informasi penting terkait operasional kepada forum agar semua manajer atau Head of Department tahu dan selanjutnya semua informasi akan disampaikan kekaryawan di masing-masing departemen agar informasi tersebar menyeluruh ke semua lapisan karyawan guna operasional dapat berjalan dengan baik.

Dari hasil wawancara yang sudah dilakukan baik komunikasi ke atas, ke bawah, atau ke samping sudah cukup efektif. Cara penyampaian informasi, etika berkomunikasi dan tingkah laku keseharian karyawan sudah cukup baik. Hanya saja tingkat profesionalitas, rasa ingin tahu dan team work dirasa perlu ditingkatkan untuk memaksimalkan iklim komunikasi yang positif. Setelah melakukan wawancara juga yang mengacu pada hal-hal yang bisa mengembangkan iklim komunikasi dilihat dari indikatornya menurut Pace \& Don F. (2001) kepada 6 karyawan reservasi yang terdiri dari Reservation Manager Ibu Kristina, Reservation Agent yaitu Asty, April, Deri dan Novi didapatkan hasil sebagai berikut.

Dilihat dari faktor kepercayaan atau dukungan dimana dengan kepercayaan atau dukungan ini membuat para karyawan reservasi menjadi lebih percaya diri, berani mengambil keputusan dan bekerja dengan semangat karena merasa ada dorongan dari luar, berupa dukungan dan reward berupa cash money dari pencapaian nilai resavision (tes pengaplikasian standar penanganan reservasi internasional). 
Sedangkan dari dalam diri sendiri berupa rasa percaya diri yang muncul yang juga merangsang naluri bekerja untuk bisa lebih menjadi pribadi yang jauh baik lagi karena mendapatkan kepercayaan atau dukungan dari atas ke bawah, antar sesama karyawan, dan dari bawah ke atas. Dukungan dari atasan sangat penting dalam organisasi (Fatikh \& Panuju, 2018) karena dapat menimbulkan keberanian untuk mengambil keputusan, bahkan dalam keadaan yang sangat krusial dan mendadak. Ketidak beranian di level bawah menurut Panuju (2002) menjadi awal munculnya krisis organisasi dan dalam pandangan kehumasan menimbulkan ketidak percayaan (distrust) dari lingkungannya.

Kepercayaan ini membuat karyawan reservasi lebih ingin melakukan explorasi diri. Terbukti didapatkan informasi juga karyawan reservasi berharap untuk mendapatkan tugas atau training menyeluruh sebagai latihan dan kecakapan dalam melakukan semua tugas seorang reservasi dengan lebih matang lagi. Bahkan mereka mempunyai keinginan untuk maju dengan mengajukan pelatihan pelatihan internal tentang pemasaran melalui media online. Sebab layanan reservasi hotel cenderung beralih melalui online. Sebagaimana diterangkan Rahman \& Panuju (2017) pemasaran melalui media sosial, khususnya instagram merupakan sebuah alternatif yang cenderung semangat diminati masyarakat

Dilihat dari faktor pengambilan dan pembuatan keputusan berkenaan dengan hotel atau operasional, untuk hal ini khusus untuk karyawan reservasi PBLB. Terkadang dilibatkan namun juga tidak jarang tidak dilibatkan. Kedua hal ini pastilah ada yang melatar belakangi. Semua karyawan reservasi dapat mengambil keputusan dan membuat keputusan dimana suatu masalah atau persoalan menyangkut kenyamanannya dalam bekerja atau sesuatu hal yang menyangkut hak dan kewajiban berkenaan dengan tugas seorang reservasi itu sendiri. Namun jika suatu masalah atau suatu informasi itu sedikit berbau rahasia berkenaan dengan manajemen atau suatu yang hanya layak untuk diputuskan manajemen seperti suatu kebijakan maka tidak akan dilibatkan.

Melibatkan karyawan reservasi dalam pengambilan keputusan membuat para karyawan reservasi menjadi mendapatkan kebanggaan tersendiri, bisa belajar mengambil keputusan yang baik, dan memastikan semua hal sesuai dengan yang diharapkan. Begitu juga sebaliknya. Hasil wawancara juga menunjukkan bahwa kekecewaan dan rasa kurang dihargai juga bisa dirasakan ketika suatu keputusan dikeluarkan tanpa adanya campur tangan reservasi, lebih-lebih kepada keputusan yang berhubungan dengan operasional dari reservasi itu sendiri. Hal ini dapat mempengaruhi situasi kerja yang sulit dan semakin kompleks ketika keputusan itu dirasa memberatkan kinerja tim dan iklim komunikasi yang terjalin di kantor reservasi menjadi buruk. Dari hal ini dapat dikatakan bahwa pengambilan keputusan bersama juga dapat mempengaruhi iklim komunikasi kerja reservasi. Tim manajemen dirasa perlu untuk melibatkan karyawan untuk pengambilan keputusan lebih-lebih yang berbau operasional reservasi untuk kenyamanan kerja dan peningkatan iklim komunikasi yang lebih baik.

Dipantau dari faktor kejujuran ini juga berkaitan dengan faktor pengambilan keputusan diatas. Semua karyawan reservasi harus mampu mengatakan dan mengutarakan kejujuran dalam pengambilan keputusan sehingga keputusan hasil akhir nanti dapat memaksimalkan kerja dan pencapaian tujuan 
yang diharapkan dan pastinya bersumber pada iklim komunikasi yang memberikan kenyamanan karena semuanya sudah berdasarkan dari hal-hal yang memang diinginkan berkaitan dengan operasional tanpa meninggalkan standard operasional yang ada. Semua berkata jujur dapat memberikan kenyamanan dan memberikan kualitas iklim komunikasi yang baik.

Kejujuran yang keluar dari lubuk hati akan mempengaruhi ekspresi ketika melayani pelanggan. Bahkan juga akan mempengaruhi tampilan bahasa tubuh. Hadipoero \& Panuju (2018). Menemukan pembenaran bagaimana bahasa tubuh memberikan kontribusi yang sangat besar dalam kepuasaan publik dalam layanan prima yang dilakukan oleh Unit Pelayanan Terpadu Satu atap di Pemerintahan Kota Surabaya.

Diteliti dari keterbukaan terhadap komunikasi ke bawah dan mendengarkan komunikasi ke atas. Seperti yang sudah di singgung terdahulu dari hasil wawancara dikatakan dari tingkat komunikasi ke atas merasakan betul dukungan dari bawah sehingga dapat melakukan semua tugas dengan maksimal sesuai kapasitas dan otoritas yang seharusnya. Namun didapatkan pula keterbukaan dari atas ke bawah kadang mengecewakan. Hal ini terjadi karena adanya perbedaan persepsi, cara pandang dan pengalaman menyikapi suatu permasalahan atau fenomena yang terjadi. Ketika suatu informasi itu didapatkan atau cara pandang bertemu pada satu suara maka komunikasi dirasa semakin baik. Melihat dari hal itu pemahaman dan keterbukan informasi ke bawah dan mendengarkan ke atas harus benar-benar bisa dimaknai dan diaplikasikan dengan baik agar dapat menciptakan iklim komunikasi kerja yang lebih baik.

Dilihat dari faktor untuk bisa mencapai tujuan dan kinerja tertinggi dari level manajemen menjadi contoh model bagi bawahan untuk mencapai tujuan dan kinerja tertinggi, mampu memberikan motivasi dan tidak menyalahi aturan. Namun saat ini dirasakan adanya kurang diperhatikannya untuk pencapaian jenjang karir sehingga untuk bisa upgrade atau mempromosikan diri ke level yang lebih tinggi dirasa masih sedikit sulit. Hal ini kadang membuat karyawan menjadi kurang bersemangat bekerja dan menunjukkan kinerja terbaik.

Adanya apresiasi membuat mereka bersemangat dan ingin menunjukkan kinerja terbaik dan pastinya ini menunjukkan iklim komunikasi terjadi semakin baik. Faktor lain pendukung pengembangan iklim komunikasi kerja karyawan reservasi didapatkan ada dua yaitu, dari dalam dan dari luar. Faktor dari dalam diri diantaranya kemampuan pola berfikir terkait menangkap atau menyampaikan suatu informasi, feedback atau cara pandang terhadap suatu fenomena sampai dengan profesionalitas, loyalitas, dan tingkah laku atau attitude.

Profesionalitas membutuhkan ketrampilan dan salah satu yang ditekankan di hotel ini adalah kemampuan menggunakan media sosial untuk mendukung jejaring konsumen atau pemasaran. Sebagaimana ditulis IA Rahman \& R Panuju (2017), pemasaran melalui media sosial sudah merupakan keniscayaan. Sebuah perusahaan yang mengabaikan media sosial akan mengalami kerugian disebabkan para pesaing sudah mulai beralih dari media konvensional atau mainstream ke media alternatif ini, dan yang tak kalah penting adalah SDM di bagian reservasi harus memiliki tingkah laku dan sikap yang baik. Untuk membentuk kemampuan ini Pulman Hotel mengadakan pelatihan-pelatihan tentang kepribadian, baik 
dengan cara mengirim SDM ke luar maupun mengundang narasumber yang kompeten ke perusahaan. Kemampuan ini berkaitan dengan kinerja karyawan yang dijarapkan dalam menunjang penjualan personal (personal salling). Suherman Kusniadji (2017) menemukan fakta bahwa meskipun interaksi antara perusahaan dengan pembeli banyak dilakukan melalui media baru seperti email, facebook, WA, instagram, namun personal salling tetap memiliki kontribusi yang besar dalam kegiatan komunikasi pemasaran. Panuju (2017) menyebutkan bahwa sentuhan kemanusiaan bisa menjadi penguat (reinforcement) dalam sistem konvergensi media. Khalayak setelah menerima terpaan informasi menghasilkan pengetahuan dan membentuk kesadaran terhadap produk dan jasa. Sentuhan kemanusiaan memperkuat keputusan yang positif ketika khalayak dalam tahap mengambil keputusan.

Sedangkan faktor dari luar yang juga ikut mempengaruhi iklim komunikasi kerja yaitu, latar belakang budaya dan kebiasaan dimana kadang menentukan penyampaian dan penerimaan pesan itu sendiri. Sejauh ini terlihat kemampuan berkomunikasi dari tim reservasi sangatlah baik dan merekapun menyadari itu sebagai modal utama melakoni profesi mereka sebagai seorang reservasi. Hal ini juga akan berujung pada sesuatu yang baik yaitu kemajuan perkembangan hotel karena semua pihak menyadari kesamaan visi dan misi dengan perusahaan. Hal yang mendasar terlihat pada kejujuran manajemen komunikasi, ketepatan gaya komunikasi, pemilihan pendekatan komunikasi dan penciptaan iklim komunikasi yang baik yang terjadi di kantor reservasi Hotel Pullman Bali Legian Beach sehingga semua pihak merasa nyaman menjalankan tugas dan kewajiban sehari hari tanpa beban.

Penerangan gaya komunikasi yang disesuaikan dengan pelanggan, merupakan bagian dari komunikasi pemasaran terpadu, yang mempunyai pengaruh terhadap equitas merek (Kartika, 2014). Sentuhan kemanusiaan merupakan bagian dari penerapan asas asas hubungan masyarakat.

\section{Simpulan}

Komunikasi dilihat dari gaya komunikasi yang dipakai sangatlah beragam mulai dari gaya komunikasi mengendalikan yang dilakukan manajemen terhadap para karyawan, terstruktur dari Manager Ibu Kristina, dilanjutkan dengan komunikasi dua arah dan sangat dinamis dilakukan oleh rekan sejawat dikantor reservasi dalam melaksanakan tugas sehari-hari. Disamping itu iklim komunikasi karyawan di bagian reservasi hotel Pullman Bali Legian Beach sudah baik. Ini terbukti dari keaktifan mereka bertukar informasi atau berinteraksi saat berada di kantor, kemampuan berkomunikasi termasuk kecakapan mereka mengoperasikan sistem komunikasi internal Opera, sampai dengan semangat mencapai tujuan. Apa yang menjadi harapan atasan sudah bisa dilampaui dan dilakukan dengan baik oleh bawahan terbukti dari konsistensi nilai audit Resavision yang selalu baik ditiap bulannya. Semua permasalahan-permasalahan terkait operasional internal dan eksternal dapat diatasi dengan bijak. Hubungan pribadi antar karyawanpun terjalin baik, didalam dan diluar kantor. Meskipun adanya sedikit kurang 
keterbukaan dari manajemen kepada karyawan terkait kejelasan mendapatkan jenjang karir meski sudah bekerja dengan maksimal.

Faktor-faktor yang dapat mempengaruhi pengembangan iklim komunikasi

para karyawan reservasi hotel Pullman Bali Legian Beach diantaranya: kepercayaan yang diberikan, pembuatan keputusan bersama yang dilakukan, kejujuran, keterbukaan dalam komunikasi ke bawah, mendengarkan dalam komunikasi ke atas, dan perhatian pada tujuan-tujuan berkinerja tinggi. Selain beberapa hal tadi juga ada beberapa faktor dari dalam diri yang mempengaruhi pengembangan iklim komunikasi diantaranya kemampuan pola berfikir terkait menangkap atau menyampaikan suatu informasi, feedback atau cara pandang terhadap suatu fenomena sampai dengan profesionalitas, loyalitas, dan tingkah laku atau attitude. Sedangkan faktor dari luar yang juga ikut mempengaruhi iklim komunikasi kerja yaitu latar belakang budaya dan kebiasaan dimana kadang menentukan penyampaian dan penerimaan pesan itu sendiri.

Kesamaan visi dan misi dengan perusahaan akan membangun kesadaran karyawan reservasi untuk mencapai tujuan kemajuan perkembangan hotel. Hal yang mendasar terlihat pada kejujuran/keterbukaan komunikasi terkait operasional, ketepatan strategi gaya komunikasi yang digunakan manejemen terhadap staf, pemilihan pendekatan komunikasi dan penciptaan iklim komunikasi yang baik yang terjadi di kantor reservasi Pullman Bali sehingga semua pihak merasa nyaman menjalankan tugas dan kewajiban sehari hari tanpa beban. Dimana nantinya hal ini akan membawa dampak kepuasan tamu yang akan bermuara pada loyalitas dan kemajuan perkembangan Hotel.

\section{Ucapan Terima Kasih}

Diucapkan terimakasih kepada I Wayan Kotaniartha, S.H, M.I.Kom (Dekan Fikom Universitas Dwijendra Denpasar) yang telah banyak memberi masukan pada luaran ini. Kepada I Wayan Swarthana, M.I.Kom yang banyak membantu dalam penelitian lapangan. Kepada Dr Otto Bambang Wahyudi, M.Si yang telah banyak mengoreksi luaran ini. Tak lupa untuk teman teman seprofesi di Hotel Pulman Denpasar yang sangat terbuka memberikan informasi/data dalam penelitian ini.

\section{Daftar Pustaka}

Arikunto, Suharsimi. (2000). Manajemen Penelitian. Jakarta: Rineka Cipta.

Himawan, Willy. (2013). Visual Tradisi Dalam Karya Seni Lukis Kontemporer Sebagai Wujud Artistik Pengaruh Sosial Budaya Kajian Terhadap Karya Haryadi Suadi \& I Wayan Sudiarta. Jurnal Ornamen, Volume 10 (1): 5781.

Rahman, IA., \& Panuju, R. (2017). Strategi Komunikasi Pemasaran Produk Rair N Pink Melalui Media Sosial Instagram. Jurnal Wacana, Vol 16 (2).

Kartika, Nia P. (2014). Pengaruh Komunikasi Pemasaran Terpadu Terhadap Equitas Merek. Jurnal Interaksi, Volume 3 (2), 162-167. 
Kusniadji, Suherman. (2017). Kontribusi Penggunaan Personal Selling Dalam Kegiatan Komunikasi Pemasaran Pada Era Pemasaran Masa Kini. Jurnal Komunikasi, $\quad$ Volume 9(2), 176-183. https://journal.untar.ac.id/index.php/komunikasi/article/view/1078/833

Fatikh, MA., \& Panuju, R. (2018). Komunikasi Organisasi Kehumasan Polres Pasuruan. Jurnal Riset Komunikasi, Volume 1 (1), 22-34.

MH, Maria., \& Panuju, R. (2018). Komunikasi Non Verbal Dalam Pelayanan Prima Di Uptsa (Unit Pelayanan Terpadu Satu Atap) Pemerintah Kota Surabaya. Jurnal Ilmiah LISKI, volume 4 (1), 13-31.

Panuju, Redi. (2002). Krisis Public Relations. Yogyakarta: Pustaka Pelajar.

Panuju, Redi. (2017). Sistem Penyiaran Indonesia. Jakarta: Kencana Prenada Mediagroup.

Panuju, Redi. (2018). Pengantar Studi (Ilmu) Komunikasi. Jakarta: Prenada Mediagroup.

Sehfuddin, A \& Mas'ud,F. (2011). PENGARUH GAYA KEPEMIMPINAN, KOMUNIKASI ORGANISASI DAN MOTIVASI KERJA TERHADAP KINERJA KARYAWAN (Studi Pada PT Bank Tabungan Pensiunan Nasional Cabang Semarang). Undergraduate thesis, Universitas Diponegoro.

Sulistyo, H. (2009). Analisis Kepemimpinan Spiritual Dan Komunikasi Organisasional Terhadap Kinerja Karyawan. Jurnal Ekonomi dan Bisnis, Volume 10(2): 311-321.

Sugiyono. (2010). Metode Penelitian Kuantitatif Kualitatif dan R\&D. Bandung: Alfabeta.

Sujatno, Bambang. (2008). Hotel Courtesy. Yogyakarta: C.V Andi Offset.

Tubbs, S.L., \& Moss, S. (1996). Human Communication: Prinsip-prinsip dasar. (Terjemahan: Dedy Mulyana). Bandung: Rosda.

Wahid, Safruddin. (2014). Komunikasi Pada Lembaga Pendidikan Nonformal. Jurnal Ilmu Pendidikan, Volume 20(1): 107-116.

Wijaya, CP \& Santoso, TPB. (2018). Strategi Pemasaran Dalam Meningkatkan Tingkat Hunian Kamar Pada Hotel Bali Mandira Legian - Bali. Jurnal Ekonomi dan Pariwisata, Volume 13 (1): 42-54. 